\title{
Geology and Geochemistry of the Chromiferous Mineralization in the External Zone of the Pan-African Dahomeyides Belt, Northwestern Benin (Gulf of Guinea, West Africa)
}

\author{
Luc Adissin Glodji1 ${ }^{*}$, Renaud Saïzonou1, Fatchéssin Bruno Adjo1, Adiss Kamal Issifou Fatiou1, \\ Soulémana Yessoufou', Basile Adjo Kanon² \\ ${ }^{1}$ Département des Sciences de la Terre, Faculté des Sciences et Techniques, Université d'Abomey-Calavi, Cotonou, Bénin \\ ${ }^{2}$ Direction Générale des Mines, Cotonou, Bénin \\ Email: ^luc.adissinglodji@fast.uac.bj
}

How to cite this paper: Adissin Glodji, L., Saïzonou, R., Adjo, F.B., Fatiou, A.K.I., Yessoufou, S. and Adjo Kanon, B. (2019) Geology and Geochemistry of the Chromiferous Mineralization in the External Zone of the Pan-African Dahomeyides Belt, Northwestern Benin (Gulf of Guinea, West Africa). International Journal of Geosciences, 10, 1068-1080.

https://doi.org/10.4236/ijg.2019.1012061

Received: October 9, 2019

Accepted: December 6, 2019

Published: December 9, 2019

Copyright $\odot 2019$ by author(s) and Scientific Research Publishing Inc. This work is licensed under the Creative Commons Attribution International License (CC BY 4.0).

http://creativecommons.org/licenses/by/4.0/

\begin{abstract}
Occurrences of chromium mineral exist in Bénin within the external nappes of the Pan-African Dahomeyides belt. These chromite deposits are podiform types and hosted in the serpentinite. Blackish color, the chromite appears under microscope in transmitted light, as cracked phenocrystals with tangles of the serpentinite venules. Chemical analyses using $\mathrm{X}$-ray fluorescence spectrometer showed the chromite ore consists of about $38 \% \mathrm{Cr}_{2} \mathrm{O}_{3}$ and total $\left(\mathrm{Cr}_{2} \mathrm{O}_{3}+\mathrm{Al}_{2} \mathrm{O}_{3}\right)$ is $60 \%$. This chromiferous mineralisation resulted from the magmatic cumulates formation by fractional crystallization of an ultramafic magma.
\end{abstract}

\section{Keywords}

Geology, Geochemistry, Chromite, Serpentinite, Buem, Benin

\section{Introduction}

Chromite is a common mineral in ultramafic rocks especially in layered intrusions and in ophiolites. It also occurs as an accessory mineral in detrital rocks [1] [2] [3] [4]. Chromite, chemical formula ( $\mathrm{Fe}, \mathrm{Mg}, \mathrm{Al}) \mathrm{Cr}_{2} \mathrm{O}_{4}$ is the most important source of chromium. This chemical element is one of the most important metals for human beings due to its use in industrial sectors (e.g. metallurgy, steel, aerospace, and telecommunication). It is also used for manufacturing of refractory materials and chemicals (such as paints, inks, plastics and medical prostheses). 
Evaluation of the economic potentials of chromite ores is based on a number of parameters, such as deposit characteristics, mineralogy and chromium content.

In West Africa, known occurrences of chromium are highlighted in the Pan-African Dahomeyides belt. This later resulted from the collision between the West African craton, the Congo craton and the East Saharan block at the end of a subduction process about $600 \mathrm{Ma}$ ago. It was formed from West to East of an external zone, a suture zone and an internal zone; its foreland is the Volta Ba$\sin$ [1] [2] [3] [4] [5] (Figure 1). In the western part of the Dahomeyides belt, geological mapping work has revealed chromite index in the external zone in Benin and in the suture zone (Agou massif) in Togo.

However, chromite deposits in the Pan-African Dahomeyides Belt of the West Africa have been poorly documented. In Benin, the chromium occurrences are reported in the Matéri region during the oldest geological mapping. These occurrences have not been the subject of extensive mining work or sustained scientific attention so that the geological context of the mineralization, mineralogy, geochemistry and chromite metallogenesis are not yet known.

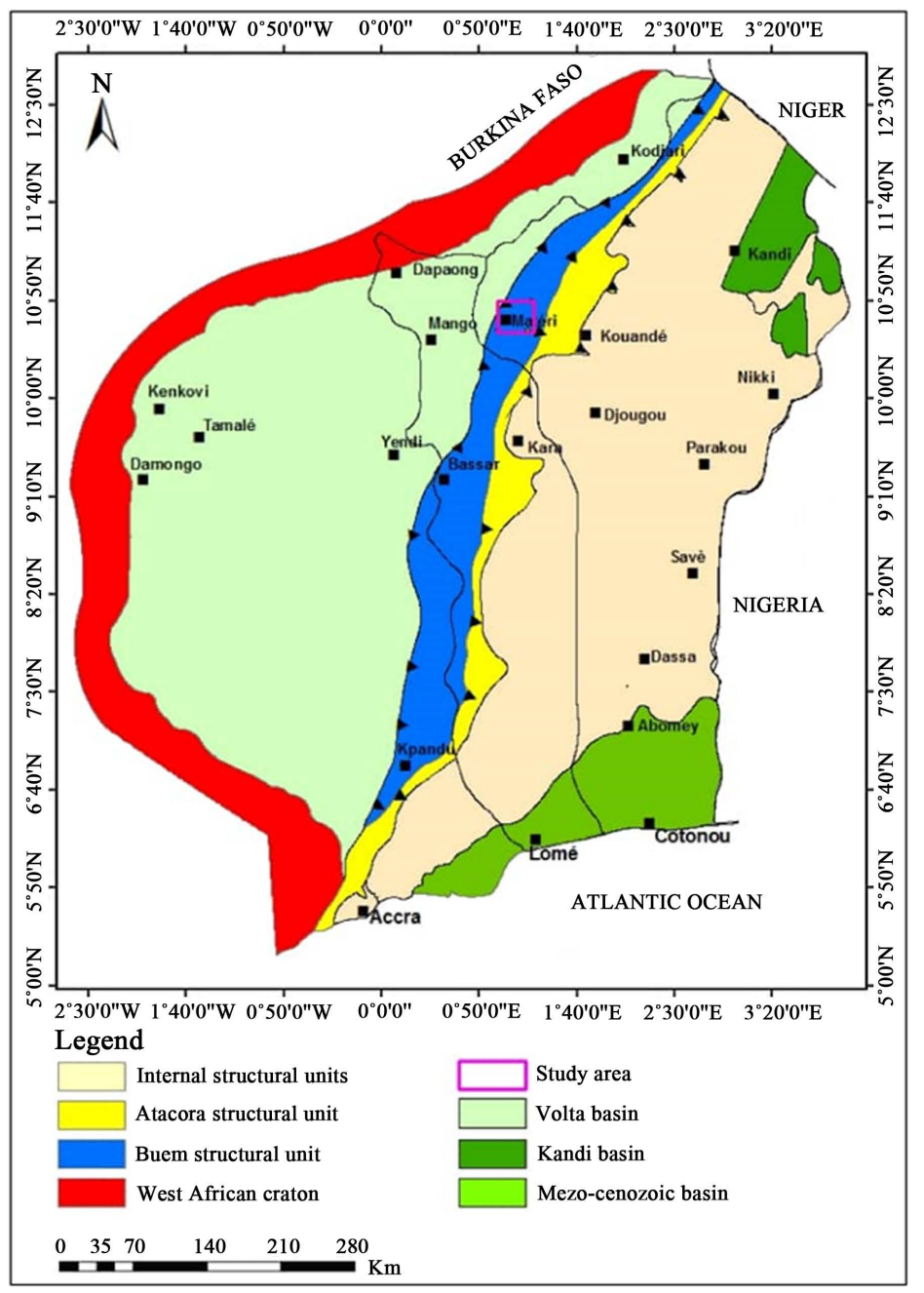

Figure 1. Simplified geological map showing main components of Dahomeyides belt [6]. 
The purpose of this paper is to present the work carried out as part of the improvement of the knowledge on the chromiferous metallogenesis and potential in the Pan-African Dahomeyides belt. Specifically, this study focuses on the geological and geochemical characteristics of the chromite in the external zone of the Dahomeyides Belt. The study area is located in the north-west of the Republic of Benin and lies between longitudes $1^{\circ} 00^{\prime}$ and $1^{\circ} 15^{\prime}$ East and latitude $10^{\circ} 35^{\prime}$ and $10^{\circ} 50^{\prime}$ North (Figure 1 ).

\section{Geological Setting}

The geological environment of the mineralized Matéri town is that of the external zone of the Pan African Dahomeyides belt. This external zone thrust to east, the sediments of the Volta Basin, which represents the foreland of the belt. The zone is subdivided into two structural units which are the Atacora structural unit and the Buem structural unit [5]. Chromiferous mineralization is found in the Buem structural unit and in the contact zone between Buem and the Volta Basin (Figure 2).

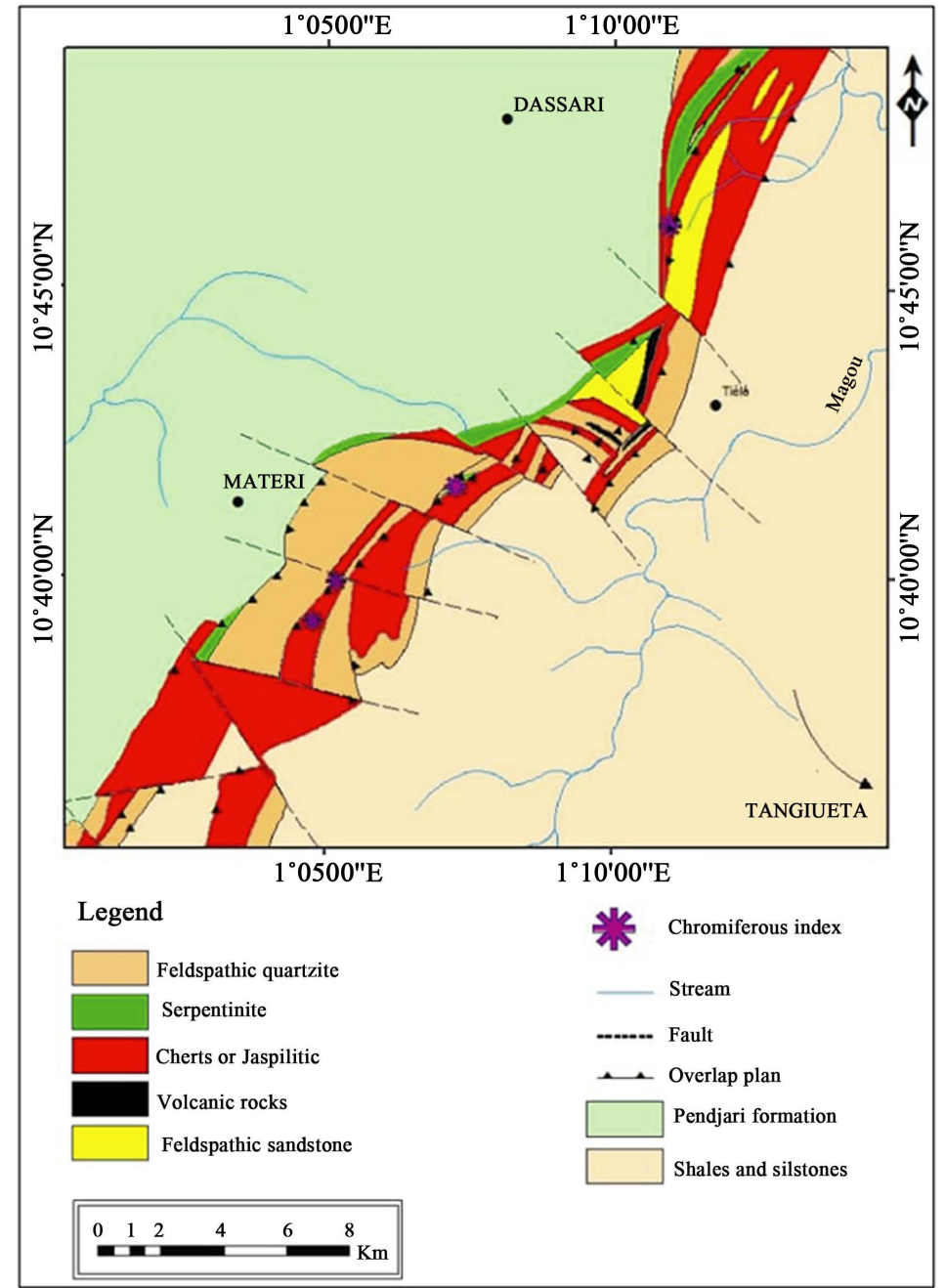

Figure 2. Localization map of the study area showing chromium index [14]. 
The sedimentary sequence of the basin is split into three super groups [5] [6]). The first two super groups yield Meso to Neoproterozoic age (1.1 to $0.6 \mathrm{Ga}$ ) and their eastern parts are involved in Pan-African orogeny. Super group I consists essentially of two sandstone groups interposed with an argillite sequence. Super group II is composed of tillite, dolomitic barite limestone and silexites at the base, and on the top alternation of argillites and siltstones locally phosphorite intercalations. Paleozoic super group III $(0.5$ to $0.3 \mathrm{Ga})$ is a molasse of the Pan-African Dahomeyides belt but does not occur in the study area.

The Buem structural unit consists mainly of low-grade metamorphism metasediments (metapellites and meta-arenites) in which meta-magmatites (serpentinites, basalts, andesite dolerites and rhyolites) are interbedded [6] [7]) (Figure 2). The metasediments of Buem are interpreted as tectonic and metamorphic lateral equivalents of the Proterozoic sediments of the Volta Basin involved in the Upper Neoproterozoic pan-African orogeny [6].

The previous geochemical data available on the chromiferous ores in the study area, concern only four (4) chromite ores samples (3 samples from Kantchekohoun and 1 from Sapoua sector) analysed by [8]. The $\mathrm{Cr}_{2} \mathrm{O}_{3}$ content of these ores range from 33\% - 35\% in Kantchékohoun and 33\% in Sapoua.

\section{Material and Methods}

The methodological approach adopted were entailed on the methods applied in the field and those implemented in the laboratory.

In the field, surface and subsurface geological prospecting work were carried out. The sectors of Wantéou, Sapoua and Kantchékohoun were investigated for studying the ores geological context. Cuttings of achieved shafts and trenches were examined. Chromite ore samples collected were studied in hand specimens and microscopic. Twenty (20) thin sections of chromite ore and its host rocks were made at the Department of Geology, University of Lomé, Togo. These thin sections were examined under a polarizing microscope in transmitted light at the Department of Earth Sciences, University of Abomey-Calavi, Bénin.

Chromite samples were also chemically analyzed at the Beninese Office for Geological and Mining Research using the Niton XL3t portable X-ray fluorescence spectrometer. The apparatus has the form of a drill or pistol and is composed of an electronic unit containing an electric X-ray generator. The measuring technique is fast, non-destructive, quantitative and has advantage to be multi-elementary. The X-ray source is a tube. The principle consist to bombard the rock with a beam of $7 \mathrm{~mm}$ of X-rays diameter in contact with the sample; the rock re-emits X-ray fluorescence radiation. The X-ray spectrum radiated by the rock is detected by the spectrometer and characterizes the sample composition. The apparatus holds a screen which makes it possible to read the elemental composition of the rock (i.e. the metallic elements contents).

This extending $\mathrm{Cu}-\mathrm{Zn}$ spectrometer analyzes elements such as copper $(\mathrm{Cu})$, cobalt (Co), molybdenum (Mo), niobium ( $\mathrm{Nb}$ ), zirconium ( $\mathrm{Zr}$ ), strontium $(\mathrm{Sr})$, rubidium $(\mathrm{Rb})$, lead $(\mathrm{Pb})$, iron $(\mathrm{Fe})$, antimony $(\mathrm{Sb})$, manganese $(\mathrm{Mn})$, titanium 
(Ti), zinc $(\mathrm{Zn})$, bismuth $(\mathrm{Bi})$, chromium $(\mathrm{Cr})$, silver $(\mathrm{Ag})$, palladium $(\mathrm{Pd})$, cadmium $(\mathrm{Cd})$, wolfram $(\mathrm{W})$, nickel $(\mathrm{Ni})$ and vanadium $(\mathrm{V})$. The contents of these elements are expressed in percentage.

A total of thirty-five (35) fresh representative samples were analyzed: ten (10) in the Sapoua and Wantéou areas, respectively, and fifteen (15) in the Kantchékohoun sector. On each chromiferous sample, we made ten measures. By sample, the geochemical analysis was performed on four sides and the average contents of the metallic elements for the sample are calculated by the arithmetic average method. Their average is for each element the average content of the element in the sector (Table 1).

Afterwards, a qualitative study of the ore was carried out for assessing the quality of the Matéri chromiferous mineralization. To achieve this, the data from the chemical analysis results have been used to calculate the percentage of $\mathrm{Cr}_{2} \mathrm{O}_{3}$ and $\mathrm{FeO}$. The method used is that proposed by [9]. The element content (El) is equal to the oxide content $(\mathrm{Ox})$, multiplied by the conversion factor $(\mathrm{a} \mathrm{OX})$ : $\mathrm{El}=$ $\mathrm{a} O \mathrm{OX}^{*} \mathrm{Ox} \Rightarrow \mathrm{Ox}=\mathrm{El} / \mathrm{a} \mathrm{OX}$.

The conversion factors of some oxides:

- $\mathrm{aCr}_{2} \mathrm{O}_{3}=0.68$

- $\mathrm{aFeO}=0.78$

Therefore, $\mathrm{Cr}_{2} \mathrm{O}_{3}=\mathrm{Cr} / \mathrm{aCr} \mathrm{O}_{3} ; \mathrm{FeO}=\mathrm{Fe} / \mathrm{aFeO}$

\section{Results}

\subsection{Geology and Petrography of Chromites}

\subsubsection{Chromium-Bearing Rocks}

The geological formations bearing the mineralized chromium sector include serpentinites, silexites and feldspathic sandstones.

- Serpentinites

The serpentinites occupy a stratigraphic position between sandstones and

Table 1. Synthesis of the average chemical compositions of the chromites of each sector.

\begin{tabular}{cccc}
\hline Content (\%) & Wantéou & Sapoua & Kantchékohoun \\
\hline $\mathrm{As}$ & - & - & - \\
$\mathrm{Pb}$ & - & - & - \\
$\mathrm{Zn}$ & 0.03 & 0.046 & 0.055 \\
$\mathrm{Ni}$ & 0.247 & 0.24 & 0.142 \\
$\mathrm{Fe}$ & 9.979 & 10.81 & 11.924 \\
$\mathrm{Mn}$ & 0.203 & 0.194 & 0.157 \\
$\mathrm{Cr}$ & 18.329 & 26.468 & 23.933 \\
$\mathrm{~V}$ & 0.002 & 0.027 & 0.022 \\
$\mathrm{Ti}$ & 0.017 & 0.026 & 0.002 \\
$\mathrm{Co}$ & 0.002 & - & 0.002 \\
$\mathrm{Zr}$ & - & - & 0.002 \\
\hline
\end{tabular}


silexites (Figure 3, Figure 4) and have a light green to dark green color. They are dense, massive and sometimes schistose (Figure 5), and present a NNE-SSW to NE-SW trending schistosity planes with a moderate dip $\left(40^{\circ}-45^{\circ}\right)$ toward the south and southeast. The thin section study of serpentinites shows a fibrous micro-cryptocrystalline mesh structure, sometimes porphyritic.

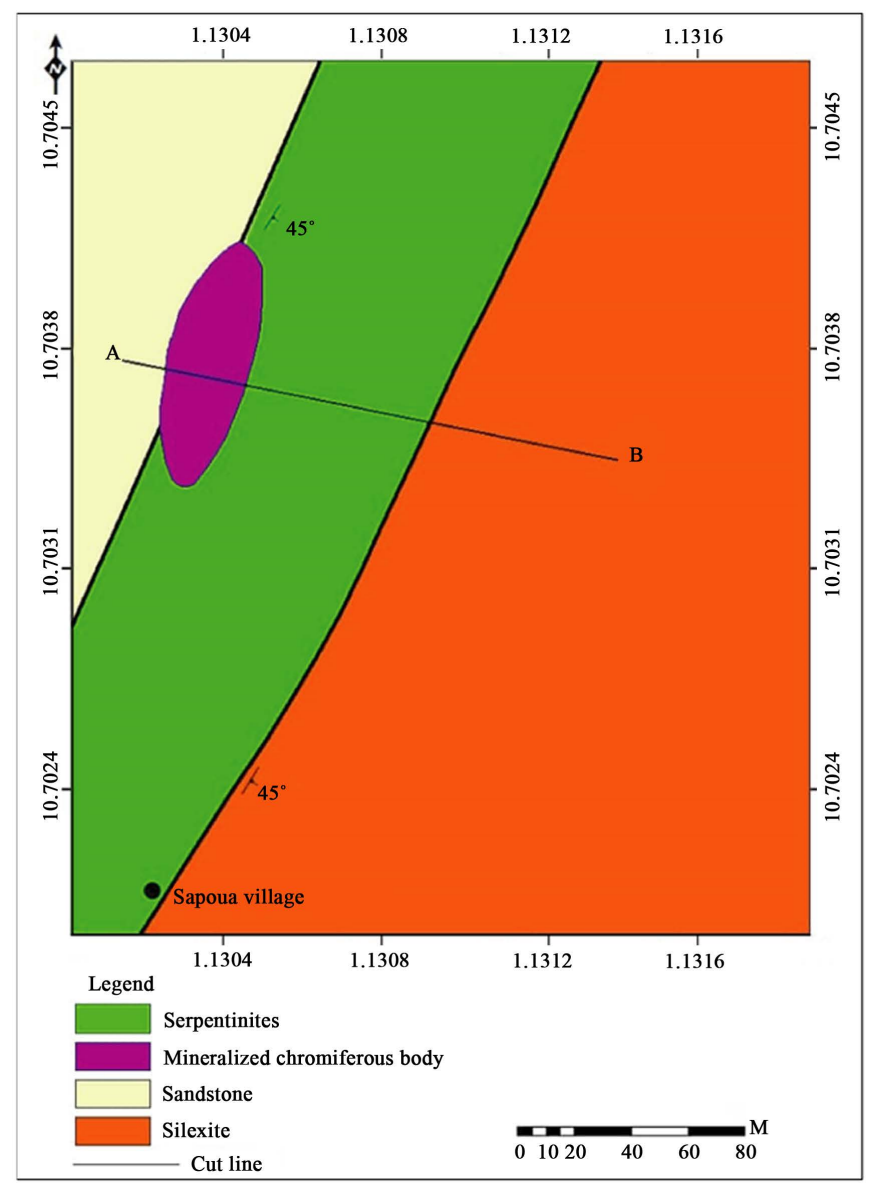

Figure 3. Chromite sitemap of Sapoua.

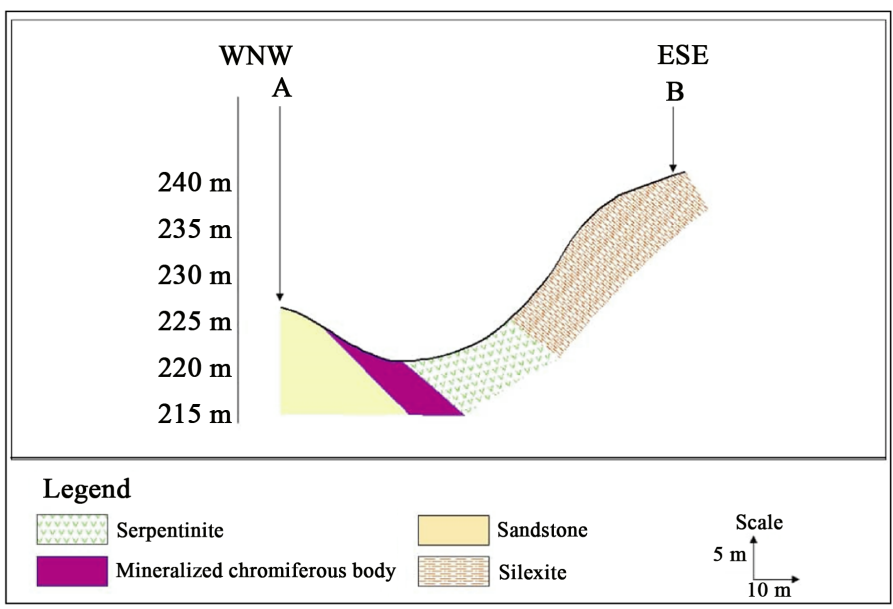

Figure 4. Cross-section of chromite sector in the Sapoua area. 


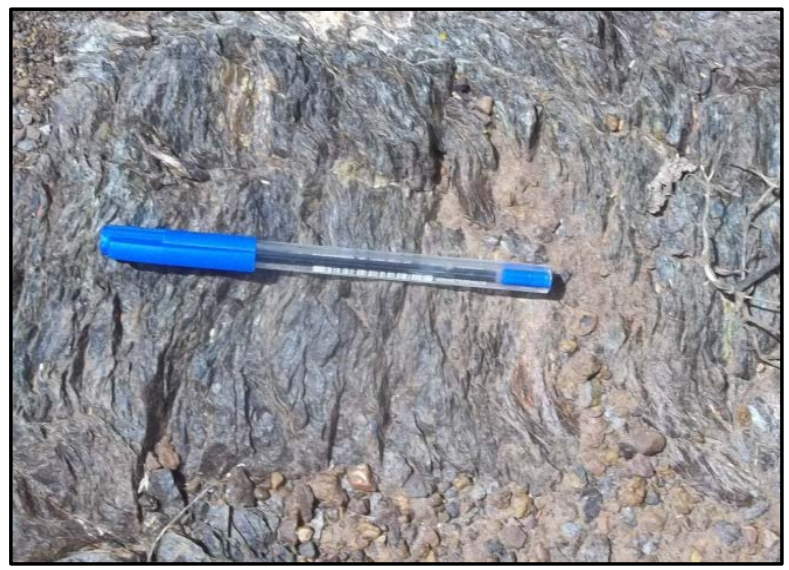

Figure 5. Field photography showing schistose serpentinite in the Wantéou sector.

Under polarizing microscope, it is impossible to exactly determine the fibrous minerals type. Note that the serpentinization process has altered the primary rock. The mesh structure indicates an alteration of an olivine-rich rock, probably a peridotite.

- Silexites

They are reddish brown and reddish, sometimes greyish with a polygonal cut (centimetric to decimetric). They show a massive texture sometimes stratified with an alternation (millimetric) of quartz and hematite crystals beds. Silexite is intersected by numerous white quartz veinlets varying from millimeter to centimeter thickness.

In thin section, the silexites show a microcrystalline equigranular structure, occasionally a botryoidal structure. Their mineralogy is very simple since the rock is always composed of microcrystalline quartz grains (almost $80 \%$ ) between which microscopic iron oxide particles have been scattered.

\section{- Sandstone}

The sandstones have a gray-white, yellow-brown and locally light greenish color. They often present a massive structure. They separate in irregular planes forming polygonal blocks from decimetre to metric. The lithologies are almost always intersected by numerous veinlets, composed of quartz mosaics. Sandstone has a granular texture and formed of quartz grains (60\%) and feldspars $(30 \%)$ in a clay matrix in which flakes of white mica are crystallized. Quartz and feldspars are sub-rounded suggesting a distal origin.

\subsubsection{Chromites}

The chromite mineralized bodies extend from southwest of Matéri to Bontomo northwest of Wanteou, more than $65 \mathrm{~km}$ long. Geological surveys were carried out in the Sapoua, Wantéou and Kantchkohoun sectors. In the former, chromiferous mineralization occurs in the form of a lens trending NNE-SSW (Figure 3 ), about sixty meters long and about twenty meters wide and intersected by WNW-ESE trending fractures (Figure 6). At Wantéou and Kantchekohoun, the ore body is intensely fractured and fragmented into centimetric to metric blocks. 


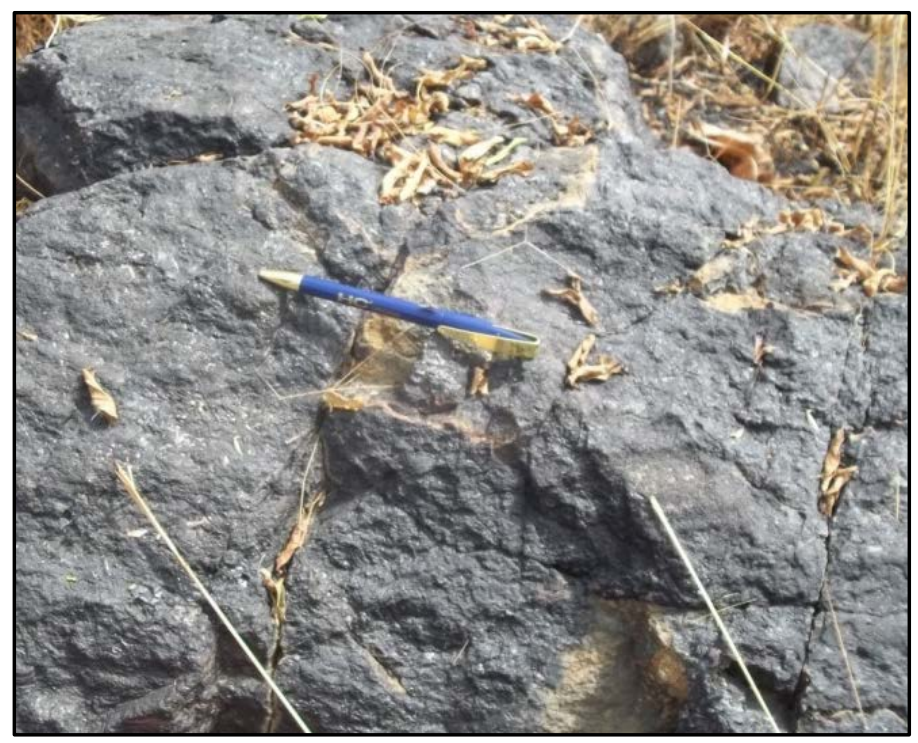

Figure 6. Field photography showing mineralized chromite body in the Sapoua sector.

These blocks are tiered on the hillsides on the one hand, and dispersed in the alterites at the top of some silexites hillsides on the other hand (Figure 7).

A black-coal and very dense chromite is commonly observed in the study area. In thin section, chromium minerals occur in phenocrystals of varied size or in opaque grains (Figure 8). These grains are often xenomorphic and cracked whilst larger crystals show entanglements of serpentine veinlets (Figure 9). The borders of the chromite grains are more opaque than the heart; this could indicate a change in the iron content of the heart towards the grain border.

\subsection{Geochemical Analysis of Chromite Ores}

In Table 1 are synthetized the average contents of some chemical elements in the mineralized chromite of each sector. Table 2 represents the conversion of the measured contents (percentage of oxide) with the portable R-X fluorescence spectrometer.

From reading Table 1, the chromium content of chromite ores varies from $18 \%$ to $26.50 \%$. The lowest chromium content is obtained in the Wantéou sector (18.33\%) and the highest in the Sapoua sector (26.47\%). The Kantchekohoun deposit shows intermediate grades (23.93\%). The nickel content in chromite ores is not negligible compared to its abundance in the earth's crust, which is 80 to 90 ppm.

Calculation of the main oxides content of the chromite ore (Table 2) reveal that the $\mathrm{Cr}_{2} \mathrm{O}_{3}$ contents vary from $26.96 \%$ to $38.94 \%$; and the $\mathrm{Cr} / \mathrm{Fe}$ ratio is from 1.84 to 2.45 .

\section{Discussion}

The work carried out make it possible to specify the chromite mode of deposition, their chemical composition and to propose their genesis. 


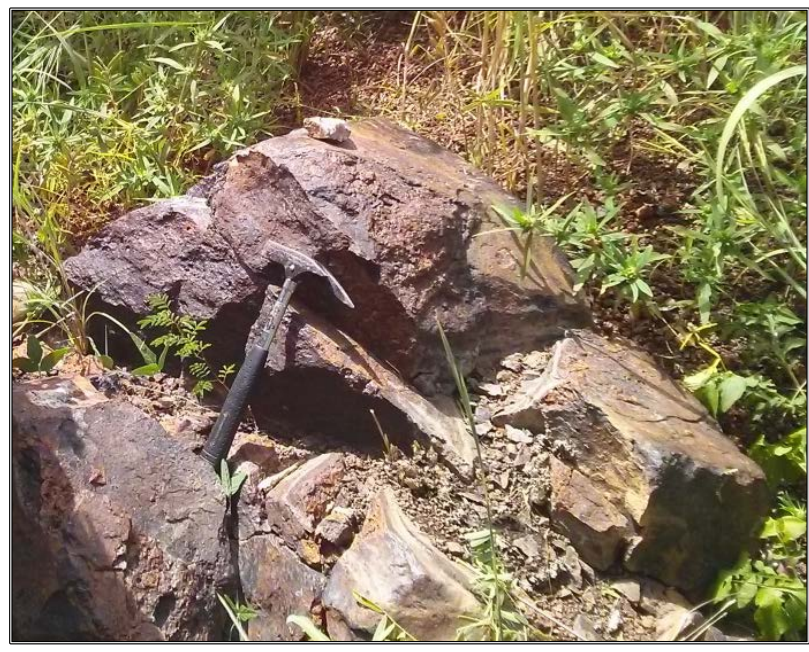

Figure 7. Field photography showing chromite blocks from Wantéou.

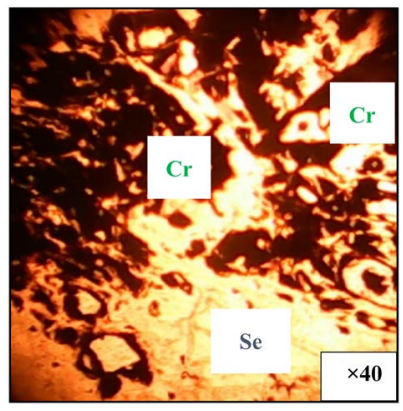

Figure 8. Microphotography showing chromite in the serpentinite. (LP); Cr: chromite. Se: serpentine.

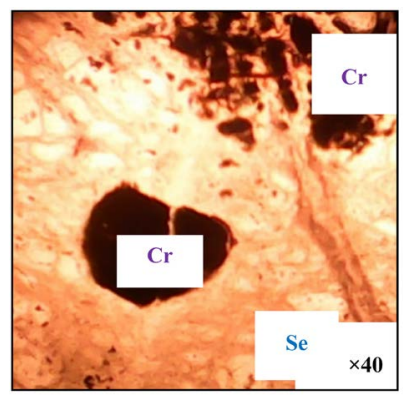

Figure 9. Microphotography showing chromite in the serpentinite. (LP); Cr: chromite. Se: serpentine.

Table 2. Calculated oxides content of chromite in the studied areas.

\begin{tabular}{cccc}
\hline Content & Wantéou & Sapoua & Kantchékohoun \\
\hline $\mathrm{Cr}_{2} \mathrm{O}_{3}(\%)$ & 26.96 & 38.94 & 35.19 \\
$\mathrm{FeO}(\%)$ & 12.79 & 13.86 & 15.28 \\
$\mathrm{Cr}(\%)$ & 18.33 & 26.47 & 23.93 \\
$\mathrm{Fe}(\%)$ & 9.98 & 10.81 & 11.92 \\
$\mathrm{Cr} / \mathrm{Fe}$ & 1.84 & 2.45 & 2
\end{tabular}


Regarding the deposit mode, field observations reveal that the deposit occurs in serpentinites and metasilexites in the elongated lenses form NNE-SSW trending. This deposit trend is parallel to the schistosities of host rocks and the deposit is dislocated and deformed. Brittle deformation of chromite led in some places to brecciation or disintegration into blocks. Thus, the chromite deposit of the external zone of the Dahomeyides belt exhibits the characteristics of podiform deposits according to the classification of chromite occurrences [10]. There are also chromites stratiform-type in the world, but these deposits are characterized by a tabular form and are often associated with basic and ultrabasic massifs [10]. The podiform chromites are associated with ophiolitic complexes or peridotitic massifs and exposed a lenticular to irregular shape, often extended and ranged along the tectonites structure [10]. Often, they are more abundant in the tectonized part at the ophiolitic sequence base, in the mantle peridotites, but also present in the dunitic cumulates of the basal sequence [10]. Such podiform chromite deposits are known in the Nuggihalli Schist Belt (Dharwar Craton), Southern India [11] [12] in Rutland Island ophiolites, part of the Burma-Andaman-Java subduction complex within Bengal Bay [4].

From the chemical composition, the studied ores are chromium-rich. $\mathrm{Cr}_{2} \mathrm{O}_{3}$ content of chromites ranges from $27 \%$ to $39 \%$. These data confirm that podiform chromites are chromium-rich and have good metallurgical quality [13] [14]. Chemical composition average comparison between the External zone of the Dahomeyides belt chromiferous mineralisation and major mined/commercialized chromite ores within the world are similar (Table 3) [15]. Thus it can be deduced that the chromite of the external zone of the Dahomeyides belt are qualitatively good and can be used in metallurgical processes to produce stainless steel.

Table 3. Typical composition of chromite ores from major producers countries through world ${ }^{\mathrm{a}}$.

\begin{tabular}{cccc}
\hline & \multicolumn{3}{c}{ Composition chemical } \\
\cline { 2 - 4 } Countries $^{\mathrm{a}}$ & $\mathrm{Cr}_{2} \mathrm{O}_{3}(\%)$ & $\mathrm{FeO}(\%)$ & $\mathrm{Cr} / \mathrm{Fe}$ \\
\hline South Africa & 44.4 & 19.8 & 1.96 \\
Kazakhstan & $54-91$ & 12.41 & 3.9 \\
India & 51.5 & 12.5 & 3.6 \\
Zimbabwe & 49.2 & 18.27 & 2.4 \\
Turkey & $34-42$ & 14 & 2.8 \\
Madagascar & 42 & $13-16$ & 2.5 \\
Finland & 35.5 & 18.3 & 1.76 \\
Iran & $40-52$ & & $2.8-3.5$ \\
Ruaaia & 39 & 18.8 & 1.8 \\
Brazil & 41.0 & 13.98 & 2.7 \\
Bénin & 33.7 & & 2.1 \\
\hline
\end{tabular}

${ }^{a}$ Papp (2010), bthis study. 
Geologically, this study attempted to propose for the first time that chromiferous ores of the Dahomeyides belt are generated by fractional crystallization of an ultramafic magma following distension and compression phases. Indeed, the study area is a transition zone that experienced two major tectonic phases during the Neoproterozic orogeny: distension phase and compression phase. During the former, the lithospheric layer was weakened, i.e. strongly thinned, which allowed mantle ultramafic magma to rise as evidenced by the presence of metabasites in the Tiélé zone which proceed from tholeiitic magma [5] [8]. During compression, the previously ultrabasic rocks were remobilized along large overlapping planes. Such phenomenon could explain the serpentinization of the ultramafic rocks of the external zone, Dahomeyides belt. These serpentinites are frequently located along large nappes or overlapping planes where they act as a soap layer. The serpentinites of the Buem unit are massive to schistose and locally chromiferous. The serpentinites being the protore of the chromiferous mineralization, during the rise of the magma, the crystals would have accumulated by density difference leading to a change of the residual magma composition, hence the chromite-rich layer formation.

In the study area, chromium bearing silexites are also observed without being associated with ultramafic rock. Silexite is part of the Eocambrian glaciogenic triad deposited during proto-oceanization [5]. Thus the depositing of silexite is anterior to the major distension phase and anterior to the original magma rise. The presence of chromite lenses in the silexites would explain by the thrusting occurred during compression phase where the chromites are embedded in silexites.

From all these observations, we infer that the genesis of the chromites within the external zone results from the magmatic cumulates formation by fractional crystallization of an ultramafic magma. In the extension context, ultramafic magmas intruded the continental crust. The chromite is raised to the surface through tangential tectonics in the external zone of the Dahomeyides belt. This chromite genetic model was also proposed by Beaudoin [10] for explaining the formation of large chromite deposits.

\section{Conclusions}

The study area contains several outcropping and sub-outcropping occurrences of chromites having a good quality. The study carried out is aimed at characterizing the chromiferous mineralization and its host rocks in the Matéri area.

The chromiferous mineralization is essentially hosted in serpentinites and associated with these ultramafic rocks in the study area. This mineralization would be related to the extension context that takes place before the Pan-African orogeny. The chemical and mineralogical study of the chromites from various sectors showed that the ore contains almost $38 \%$ of $\mathrm{Cr}_{2} \mathrm{O}_{3}$. These chromites can be high-quality on the metal market for the refractory industry.

Subsurface work and magnetometer surveys are recommended as follows: this result in order to investigate the development of ore bodies in deep, assesses the 
rooting of mineralization in the various areas, and assesses the chromium potential of the external zone of the Dahomeyides belt in Bénin.

\section{Conflicts of Interest}

The authors declare no conflicts of interest regarding the publication of this paper.

\section{References}

[1] Lenaz, D. and Princivalle, F. (2005) The Crystal Chemistry of Detrital Chromian Spinel from the Southeastern Alps and Outer Dinarides: The Discrimination of Supplies from Areas of Similar Tectonic Setting? The Canadian Mineralogist, 43, 1305-1314. https://doi.org/10.2113/gscanmin.43.4.1305

[2] Pownceby, M. (2005) Compositional and Textural Variation in Detrital Chrome-Spinels from the Murray Basin, Southeastern Australia. Mineralogical Magazine, 69, 191-204. https://doi.org/10.1180/0026461056920246

[3] Pownceby, M. and Bourne, P. (2006) Detrital Chrome-Spinel Grains in Heavy Mineral Sand Deposits from South East Africa. Mineralogical Magazine, 70, 51-64.

https://doi.org/10.1180/0026461067010312

[4] Ghosh, B., Pal, T., Bhattacharya, A. and Das, D. (2009) Petrogenetic Implications of Ophiolitic Chromite from Rutland Island, Andaman-A Boninitic Parentage in Supra-Subduction Setting. Mineralogy and Petrology, 96, 59-70.

https://doi.org/10.1007/s00710-008-0039-9

[5] Affaton, P., Rahaman, M.A., Trompette, R. and Sougy, J. (1991) The West African Orogens and Circum-Atlantic Correlatives. Springer-Verlag, Berlin, 7-122.

[6] Affaton, P. (1987) Le bassin des Volta (Afrique de l'Ouest): A Passive Margin, of Proterozoic Superior Age, Tectonized in the Pan-African (600 $\pm 50 \mathrm{Ma})$. Thesis of doctorate of State, University Aix-Marseilles III, France, 462 p.

[7] Affaton, P., Aguirre, L. and Ménot, P. (1997) Thermal and Geodynamic Setting of the Buem Volcanic Rocks Near Tiélé, Northwest Benin, West Africa. Precambrian Research, 82, 191-209. https://doi.org/10.1016/S0301-9268(97)80686-9

[8] Jepsen, H.F. and Depciuch, T. (1974) Report on the Geological and Geochemical Prospection in the Buem Area. (Zone X)-UNDP Chromite, Project: Mining Research in Dahomey, DAH 73/006.

[9] Kamenetsky, V.S., Crawford, A.J. and Meffre, S. (2001) Factors Controlling Chemistry of Magmatic Spinel: An Empirical Study of Associated Olivine, Cr-Spinel and Melt Inclusions from Primitive Rocks. Journal of Petrology, 42, 655-671.

https://doi.org/10.1093/petrology/42.4.655

[10] Georges, B. (2006) Gitology and Metallogeny. Manual of Gitology and Metallogeny GLG-10351. Geology and Geological Engineering, Faculty of Science and Engineering. Laval University, Quebec, 48 p.

[11] Channabasappa, S. (2011) Mineragraphic Studies of the Chromites from Nuggihalli Schist Belt, Dharwar Craton, Southern India. International Journal of Earth Sciences and Engineering, 4, 309-316.

[12] Mukherjee, R., Frei, R., Mondal, S.K. and Rosing, M.T. (2010) Compositional Variations in the Mesoarchean Chromites of the Nuggihalli Schist Belt, Western Dharwar Craton (India): Potential Parental Melts and Implications for Tectonic Setting. Contributions to Mineralogy and Petrology, 160, 865-885.

https://doi.org/10.1007/s00410-010-0511-5 
[13] Leblanc, M. and Ceuleneer, G. (1992) Chromite Crystallisation in a Multicellular Magma Flow: Evidence from a Chromitite Dike in the Oman Ophiolite. Lithos, 27, 231-257. https://doi.org/10.1016/0024-4937(91)90002-3

[14] Jébrak, M. and Marcoux, E. (2008) Geology of Mineral Resources. 667 p.

[15] Papp, J. (2010) 2008 Minerals Yearbook Chromium. United States Geological Survey. 